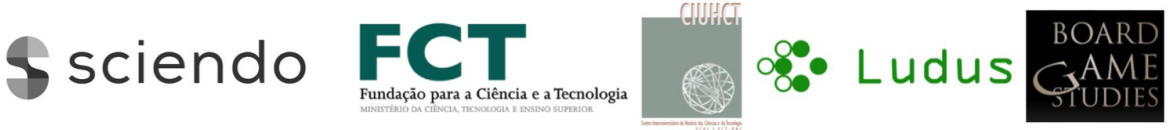

\section{WRESTED FROM OBLIVION: GENERAL LUDWIK MIEROSŁAWSKI'S STRATEGY GAME REDISCOVERED}

\author{
Oliver Heyn \\ Independent Researcher
}

\begin{abstract}
During the first half of the 19th century, liberal and nationalist uprisings erupted in all corners of Europe. While militant revolutionaries fought against restorative monarchies for more tolerant legislation or even full national independence, their countries slid into turmoil. In this European struggle, which set parts of Germany, Poland, France and Italy aflame, Ludwik Mierosławski (1814-1878) was one of the key insurgents. Besides being a keen partisan of Polish independence, Mierosławski enjoyed thorough military training and proved himself an astute theoretician of military strategy. It might be argued that he was probably one of the most inventive minds of his time, creating among other things an early tank vehicle and a bulletproof knapsack that could be used as a shield.

This article brings a hitherto unknown invention of Mierosławski to light: A strategy game depicting military maneuvers on an abstract map. Defying complicated rules and adhering to pure simplicity, the game was both fast-learning and captivating. Moreover, contemporary critics praised its way of introducing players to the fundamentals of strategic thinking and military geography. Several matches were even played at the French military academy at St. Gyr in 1858. The extensive research of this article not only reveals the background of Mierosławski's invention but also his methods of making the complete game public. The last chapter of this contribution contains a summary of the game rules, enabling the readers to bring this invention to life by themselves. In the end, the study of his game allows us to approach and discover Mierosławski's ideas and ways of thinking, thereby shedding further light on this complex personality.
\end{abstract}

\section{Introduction}

On the morning of February 12, 1846, Ludwik Mierosławski was taking a bath in his study room at the Swiniary manor, just a few kilometers to the

Board Game Studies Journal 14, pp. 17-42 DOI: $10.2478 /$ bgs-2020-0002 
northeast of Gniezno in Poland. Here he lived under disguise on the estate of a friend and was busy preparing final instructions concerning an imminent uprising. The insurrection was scheduled for the end of February and should include large areas of Poland which were under Prussian and Russian control since the Congress of Vienna in 1815. Mierosławski was the most important figure in this scheme and was at the head of the rebellion. Because he had a distinguished talent for coordination and logistics, the insurgents military planning was assigned to him. ${ }^{1}$ However, what Mierosławski could not have foreseen was the treason of a Polish nobleman who alerted the Prussian police at Poznan and revealed details of the forthcoming uprising. So, while Mierosławski was taking his bath, Prussian constables began to close off the Swiniary manor. Although he jumped out of the bathtub and burned some compromising documents, he was unable to destroy all evidence and could not escape. With the leader arrested, the Greater Poland Uprising of 1846 ended even before it really began. ${ }^{2}$

Mierosławski was detained in Poznan but due to security reasons he was transferred to a newly constructed prison at Berlin-Moabit. Beside him there were 254 other conspirators arrested and finally brought before trial in one of the biggest lawsuits in German history. Because so much evidence had to be secured and reviewed, the process began only after one and a half years in August 1847.3

Detained and awaiting trial, Mierosławski prepared his defense which later drew great attention and led to eloquent speeches before the court. In the seclusion of his prison cell and unobserved by the public he spent much time with the invention of a strategy game. The development of this today largely forgotten game can only be understood by considering Mierosławski's educational background. Scientific studies have almost exclusively described Ludwik Mierosławski as a political person and neglected his commitment to the military sciences. His strategy game is an

\footnotetext{
${ }^{1}$ Anhang. Betheiligung der einzelnen Angeklagten, in Der Polenproze $\beta$. Prozeß von dem Staatsanwalte bei dem Königlichen Kammergerichte als Betheiligte bei dem Unternehmen zur Wiederherstellung eines polnischen Staates in den Grenzen vor 1772 wegen Hochverraths angeklagten 254 Polen, ed. Gustav Julius (Berlin, 1848), 3-4.

2 Arnon Gill, Die Polnische Revolution 1846, (Munich, 1974), 186.

3 Daniela Fuchs, "Der große Polenprozess in Berlin und Bettina von Arnims Engagement für den angeklagten Mierosławski," in Ein europäischer Freiheitskämpfer. Ludwig Mierostawski 1814-1878, ed. Julia Franke (Berlin, 2006), 19-38.
} 
expression of this commitment which constitutes an important facet of his character and biography.

\section{Mierosławskis Education and Writing}

A son of an émigré polish officer, who was aide-de-camp to Marshall Davout during the Napoleonic Wars, and a French mother, Mierosławski was raised bilingual. In 1820, the family moved to Russian-controlled Congress Poland where Mierosławski entered the Cadet Corps at Kalisch four years later and in 1830 became an officer candidate in the 5th Regiment of the Line. ${ }^{4}$ Prior to the Polish November Uprising he was promoted to Lieutenant in the 3rd Regiment of Chasseurs and subsequently joined the rebels with this unit. During the ensuing fighting, Mierosławski was present at the battles of Grochow and Ostrolenka. ${ }^{5}$ To evade annihilation from Russian forces, the army corps where Mierosławski served crossed the border to Austria. After short internment he went to France, because the quite liberal July Monarchy was a safe haven for Polish emigrants and also granted refuge to many military leaders of the November Uprising. ${ }^{6}$ Mierosławski stayed at first in Avignon and Besançon but in 1835 moved on to Paris, where he acted as a spokesman of émigré organizations and was particularly engaged in writing. His first works - which were only published in Polish - dealt with the experience of revolution und emigration in lyric fashion. ${ }^{7}$ At the same time, Mierosławski was also interested in Polish History and began publishing works in French in order to reach a larger audience. Especially his three-volume work "Histoire de la Révolution de Pologne" about the history of the November Uprising gained wider recognition and positive reviews. ${ }^{8}$ His critical appraisal of the military events

${ }^{4}$ Lech Chmiel, Generat Ludwig Mierostawski 1814-1878 (Warsaw, 1975), 5-14; Marian Zychowski, Ludwig Mieroslawski 1814-1878 (Warsaw, 1963), 34-35.

${ }^{5}$ Bronisław Gembarzewski, Rodowy putków polskich i oddziałów równorzednych od $r .1717$ do r. 1831 (Warsaw, 1925), 83.

${ }^{6}$ Michel Sokolnicki, Les origines de l'emigration polonaise en France (1831-1832) (Paris, 1910), 141-84.

7 These lyric works are : Ludwig Mierosławski, Szuja (Paris, 1835), Bitwa grochowska (Paris, 1835), Zelazna Maryna (Paris 1836), Pugaczowe (Paris, 1836).

${ }^{8}$ Ludwik Mierosławski, Histoire de la révolution de Pologne (Paris, 1836). A revised edition was later published as Ludwik Mierosławski, Histoire de la révolution de 1830 à 1831 (Paris, 1842).

Board Game Studies Journal 14, pp. 17-42 DOI: $10.2478 /$ bgs-2020-0002 
occurring during the Polish Uprising demonstrated extraordinary knowledge and a deep understanding of strategic science.

Although Mierosławski had not enjoyed higher military education, he proved to be an able autodidact, who studied with great discipline and was well versed in classic works on strategy. In expectation of another Polish uprising, Mierosławski sought to put strategic theories to good use for the revolutionaries. He was convinced that an independent Poland could only be achieved through war. Indeed, Mierosławski's live-long interest for all things military rested on that assumption. Therefore, it was in accordance with his political opinion that he authored various papers on military education for militant Polish émigré circles. ${ }^{9}$ His "Critical analysis of the campaign of 1831", which was published in 1845, belongs in this context. ${ }^{10} \mathrm{It}$ is without doubt Mierosławski's most important work. In this book, the author gives a critical evaluation of the 1831 military campaign which followed the November Uprising. The content reveals a geometrical understanding of strategy and shows influence of theoretical works from well-known writers like Heinrich Dietrich von Bülow, Antoine-Henri Jomini and Archduke Charles of Austria. These theoreticians subdivided theatres of war in points and lines, i.e. strategic points, lines of operations, base of operations and operation targets. In this manner and with a little abstraction, it is possible to obtain a general overview of any landscape considered for war, while separating important from less important components. Mierosławski was the first author to supply an in-depth strategic analysis of the area between the rivers Vistula, Daugava and Dnepr while giving a detailed account of the 1831 campaign in Poland. A Prussian officer, who in 1847 translated his work into German, considered it to be a "strategic catechism for the war in the East." 1

\section{Game development}

In his various publications, Mierosławski showed great knowledge of contemporary military science. He also continued to work on this subject

${ }^{9}$ Ludwik Mierosławski, Kurs sztuki wojskowej (Paris, 1840).

10 Ludwik Mierosławski, Rozibior krytyczny kampanii 1831 roku i wywnioskowane z niej prawidta di wojny narodowej. 2 vols. (Paris, 1845).

11 Ludwik Mierosławski, Kritische Darstellung des Feldzugs vom Fahre 1831 und hieraus abgeleitete Regeln für Nationalkriege (Berlin 1847), 1:V. 
during his imprisonment in Berlin. It was probably due to the monotony of everyday prison life, that Mierosławski occupied himself with transferring the ideas of strategic theory into a practical game. Closer looks at his later rules reveal that Mierosławski was familiar with other strategical/tactial games of the time which may have inspired him.

Since the end of the $18^{\text {th }}$ century, several mathematicians and military officers tried to model simulations of war using traditional game patterns. ${ }^{12}$ They all too often came up with various rules which were neither practical nor authentic. The main problem lay in the fact, that the more realistic the game got, the more impractical it became and vice versa. But realism was the credo of the time. To illustrate the situation it suffices to consider just a few examples of early-nineteenth century war-game literature: The rulebook of Johann Christian Hellwig's tactical game from 1780 consists of several hundred special rules and proved to be unplayable. ${ }^{13}$ To play Georg Venturini's war-game of 1797 one has to remember some 200 paragraphs and even the more concise and realistic Kriegsspiel of Johann Georg Reisswitz gets impractical if the forces on both sides reach a certain size. ${ }^{14}$ In fact, around 1850 there was not one reasonably simple and instructive game which depicted military campaigns or engagements and was not merely a chess variant. Mierosławski was aware of the situation and accordingly planned his game along the lines of simplification and abstraction, in order to add playability. The design of the game board follows the theories Mierosławski described in his work on the Polish campaign of 1831: A realworld geographical landscape was examined under a military point of view. Narrowed down to its important strategic places and lines, it was then transferred to a grid of triangles which represents a road map. The length of a triangle side on the map corresponds approximately to 37 kilometers, which Mierosławski considers to be a day's march and therefore calls it "strategic stage". The triangle sides are roads where troop movement takes

12 Anders Engberg-Pedersen, Empire of Chance. The Napoleonic Wars and the Disorder of Things (Cambridge, MA, 2015), 120-33; Ulrich Schädler, "Prekäre Ordnung. ,Kriegsspiele Panoramablick auf ein schwieriges Kompositum, "in Agon und Ares. Der Krieg und die Spiele, ed. Ernst Strouhal (Frankfurt/New York, 2016), 23-44, especially 29-30.

${ }^{13}$ Johann Christian Ludwig Hellwig, Versuch eines aufs Schach-Spiel gebauten taktischen Spiels (Leipzig, 1780).

${ }_{14}$ Georg Venturini, Beschreibung und Regeln eines neuen Krieges-Spiels (Schleswig, 1797); Johann Georg Reisswitz, Anleitung zur Darstellung militärischer Manöver mit dem Apparat des KriegsSpieles (Berlin, 1824).

Board Game Studies Journal 14, pp. 17-42 DOI: $10.2478 /$ bgs-2020-0002 
place. Since roads can be of different qualities, the troop size passing different kinds of roads is limited. The same applies to defiles like river passages or mountain passes. The corner points of the triangles are strategic stations, e.g. cities, fortresses or just places to camp. Like the roads, different types of stations can only accommodate a limited size of troops. The game board or map is divided along a frontier and thereby creating two rival states with a capital and several provinces/province capitals each.

Mierosławski connected his game with actual contemporary events and in 1849 chose to use the theatre of the Hungarian War of Independence (1848-49) as a pattern for the game board. A comparison of the board layout with real-world geography reveals a slight shift in the actual position of some geographical points which is due to the triangular grid abstraction. The game board is thus only in strategic relations, but not in matters of realworld geography, an image of reality. As time progressed, Mierosławski introduced other regions and larger game boards were invented, which enabled several players to form coalitions. There was even an instruction for players to draw game board maps themselves.

The game used different types of playing pieces, which Mierosławski invented in an odd shape. They had a conic, funnel-shaped form and represented the three types "Great General Staff", "Little General Staff" and "Division". For matters of simplicity, Mierosławski did not distinguish between the different branches of service. To use the playing pieces one had to glue the paper-printed game board on cardboard or wood, then stick/cut holes at the strategic stations to enable the playing pieces to stay upright.

During a game turn, a player has the right to move each piece in a preferred direction along a triangle side, a turn thus representing a day. The aim of the game is to move the "Great General Staff" piece from the own capital to the capital of the adversary. The player entering the enemy capital with the own "Great General Staff" or capturing the opponent's "Great General Staff" wins the game. The "Great General Staff" piece has no offensive/defensive powers and on its way to the enemy capital has to be covered by the "Divisions". There is no actual combat in this game and combat resolution is based on superiority. It means that a weaker force must evade a stronger opponent and has to retreat; in case retreat is impossible, the weaker force is lost. Fortresses, river crossings etc. support the defense and influence the force ratio. In his design, Mierosławski succeeds to implement some basic rules of strategy: To win the game it is necessary to 
achieve a concentration of force on the right time and on the right spot (see the detailed rules at the end of this paper).

The concept of Mierosławskis rules bears some resemblance with a game invented by the Dutch engineer officer J. A. Messmer and published in 1819 under the title "Het strategisch spel". ${ }^{15}$ In fact, Messmer was the first one to transfer strategic situations from chessboard onto a topographical map. ${ }^{16} \mathrm{~A}$ great part of his map layout consists of an equidistant route network that is similar to a triangular grid. ${ }^{17}$ Although Messmer used a greater variety of pieces and distinguished between service branches, the combat decision follows the same pattern as in Mierosławski's design. There can only be few doubts about the fact that Mierosławski knew Messmer's game quite well and was influenced by it. He, however, facilitated the design to a great extent and added new components, thereby inventing a game of his own. While Messmer's rules are still characterized by the traits of eighteenthcentury fodder magazine system and subsistence of troops, Mierosławski concentrates on pure strategy; whereas the former employs dice, pontoon bridges etc., the latter dismisses these aspects in favor of fundamentals and simplicity. By doing so, Mierosławski succeeded in creating a simply learnable military game, which might be the most practicable invention he ever devised.

\section{Game diffusion}

Mierosławski completed his game rule manuscript in the summer of 1847, but publication proved to be difficult. The arrest of the Polish conspirators, as well as the following tribunal in Berlin with Mierosławski as a key figure, was widely reported in newspapers all over Germany and not a single publishing house was inclined to print a book written by a known revolutionary. In the end Mierosławski sent his manuscript to Wilhelm

${ }^{15} \mathrm{~J}$. A. Messmer, Het strategisch spel, of Militaire uitspanning (The Hague, 1819). A German version was published the following year, see J. A. Messer, Das Feldzugsspiel oder Militärische Erholungen zum Vergnügen und Unterricht (The Hague, 1820).

16 Sometimes wrongly attributed to Reisswitz the Older.

17 Messmer, Het strategisch spel, 1-3; Christopher George Lewin, War Games and their History (Stroud, 2012), 42 contains an image of the game board.

Board Game Studies Journal 14, pp. 17-42 DOI: $10.2478 /$ bgs-2020-0002 
Bothe who ran a little business as a lithographer in Berlin. ${ }^{18}$ With his cooperation, Mierosławski managed to publish the first rules of his game in 1847. The 16-page booklet, written in French and bearing the title "Échecs polonais" (Polish chess) constituted a very limited edition print and did not draw any public attention. ${ }^{19}$ Another edition in Polish language, published in 1848, did not better. ${ }^{20}$ Mierosławski may have been a little disappointed, yet for now there was no time to spread the rules of his game anyway: In December 1847 the trial against the Polish conspirators was concluded and Mierosławski sentenced to death. He was later pardoned to life-long imprisonment by the Prussian king Frederick William IV and finally got liberated due to an amnesty during the Revolution of 1848. This marked the starting point of Mierosławski's odyssey to the theaters of revolutionary Europe: From March to May 1848 he was the military leader of another Polish Uprising, which sought in vain to achieve all demands that failed two years before. At the beginning of 1849, Mierosławski became the head of Sicilian revolutionaries, who tried to put an end to the Bourbon monarchy of King Ferdinand II. After being wounded during the siege of Catania, Mierosławski went to Paris for recovery. In June 1849 he accepted the offer to command a revolutionary army which had formed in the German regions of Baden and the Palatinate. ${ }^{21}$ In his function as supreme commander, he managed to lead his troops quite skillfully while facing serious enemy superiority. ${ }^{22}$ So far for Mierosławski, this represented the most splendid opportunity to demonstrate his strategic skill to the world.

18 Winckler, Allgemeiner Wohnungsanzeiger für Berlin, Charlottenburg und Umgebung auf das Jahr 1846 (Berlin, 1846), 49.

19 Ludwik Mierosławski, Échecs polonaise (Berlin, 1847). It seems that no copy has survived. Up to this date it was not possible to track down a single original of the first edition in any public library worldwide. 1848).

${ }^{20}$ Ludwik Mierosławski, Szachy polskie (Berlin, 1848) and Objasnienie gry szachow (Berlin,

${ }^{21}$ Berthold Knapp, "Ludwik Mierosławski, ,Obergeneral' der Revolutionsarmee. Die Mitwirkung von Polen an der badischen Volkserhebung des Jahres 1849 im Lichte des gesamtpolitischen Freiheitskampfes, "Zeitschrift für Geschichte des Oberrheins 123 (1975): 227241; Joachim Kermann, "Die pfälzische Revolution und die Rolle der Polen," in Baden 1848/49. Bewältigung und Nachwirkung einer Revolution, ed. Clemens Rehm (Stuttgart 2002), 95-132.

22 Christian Wilhelm Pabst, Der Feldzug gegen die badisch-pfälzische Insurrection im fahre 1849 (Darmstadt, 1850); Wilhelm Rüstow, Die Feldherrnkunst des neunzehnten Fahrhunderts (Zurich, 1879), 2: 304-312.

Board Game Studies Journal 14, pp. 17-42 DOI: $10.2478 /$ bgs-2020-0002 
The contemporary judgment on his military decisions turned out to be mostly positive and even critics had to admit that Mierosławski was an educated theoretician, who also knew how to put his knowledge to practice. Nevertheless, the troops of the revolutionaries under Mierosławskis command were unfit to obtain victory and he finally decided to resign. He fled to Switzerland where he encountered Samuel Federick and Rudolf Jenni. The two brothers owned a publishing house with strict anti-clerical and radical-liberal orientation in Bern, which had among its customers such well-known revolutionary characters as Wilhelm Weitling, Gustav Struve, Giuseppe Mazzini - and now Ludwik Mierosławski. ${ }^{23}$ The authors as well as the program of the publishing house caused the German Confederation to ban all of the Jennis' publications in January 1848. ${ }^{24}$ Mierosławski nevertheless decided in 1849 to publish his reports to the revolutionary government of Baden with the aid of the Jennis' and managed to gain a large audience in Germany despite the active ban. ${ }^{25}$ At exactly the same time and virtually unnoticed, Mierosławski also published the second edition of his strategy game's rules. This time, the booklet bore the more fitting title "Geu stratégique" (Strategic Game) but again received little public attention, probably because of the dubious repute the Jenni's publishing house enjoyed in France. ${ }^{26}$

In mid-July 1849, Mierosławski was expelled from Switzerland due to a decision of the Swiss Federal Council. ${ }^{27}$ He returned to France, where he lived a secluded life in an apartment in Versailles working only infrequently as a private teacher for mathematics and history. Mierosławski became increasingly dissatisfied with the only moderate circulation of his game rules

23 Hans Gustav Keller, Die politischen Verlagsanstalten und Druckereien in der Schweiz 18401848. Ihre Bedeutung für die Vorgeschichte der Deutschen Revolution von 1848 (Bern 1935), 79-92; Thomas Christian Müller, Der Schmuggel politischer Schriften. Bedingung exilliterarischer Öffentlichkeit in der Schweiz und im Deutschen Bund (1830-1848) (Tübingen 2001), 75-79.

${ }^{24}$ Protokolle der Deutschen Bundesversammlung vom Jahre 1848 (Frankfurt, 1848), Session 170, §50, 76-79.

${ }^{25}$ Ludwik Mierosławski, Rapports du général Mierostawski sur la campagne de Bade (Bern, 1849). For the German edition, see Ludwik Mierosławski, Berichte des Generals Mieroslawski über den Feldzug in Baden (Bern, 1849).

${ }^{26}$ Ludwik Mierosławski, Jeu stratégique (Bern, 1849).

27 "Beschluss des Schweizerischen Bundesrates vom 16.07.1849" in Bundesblatt der Schweizerischen Eidgenossenschaft 1849, 2:254-57.

Board Game Studies Journal 14, pp. 17-42 DOI: 10.2478/bgs-2020-0002 
and therefore decided to work on the third edition. ${ }^{28}$ A new publisher was found in Louis Martinet, who directed a printing office in Paris and was renowned for his colored lithographs, which formed the part of several wellknown encyclopedias. The distribution of this third edition was handled by Jean Dumaine, who owned a highly reputable bookstore in central Paris that was specialized in military science. Therefore, it did not take long for Mierosławski's book to attract attention in military circles all over France.

It were the Moniteur de l'armée and the Spectateur militaire - two of the most important military journals of France - who first printed reviews of Mierosławski's game. ${ }^{29}$ Similarities in wording indicate that they all were written by the same anonymous author, who was indeed quite satisfied with the game rules and declared: "[The game board] offers the means to use the fundamental rules of strategy with regard to political geography and military matters in a way both instructive and amusing. [...] There is neither a theater of war nor a combination of troop movements that cannot be handled in a simple and precise manner by this game. "30 When a detailed advertisement was published in the greatly respected Fournal de débats at the end of March 1850, the game reached a wider public. ${ }^{31}$ The invention even received some attention in the German states, but conservative reviewers frequently tended towards derision when dealing with anything connected to Mierosławski. The role he played in the failed revolutionary uprisings between 1846 and 1849 was not forgotten and while an author for the journal "Deutsches Wochenblatt für constitutionelle Monarchie" spoke briefly of the game, he could not withhold the statement, that "everytime the game got serious [for Mierostawski] he went bankrupt."32 A more balanced appraisal can be found in the military journal "Deutsche WehrZeitung" which stated: "It is probable that General Mierostawski has used the game for his studies on the campaigns in Poland, Sicily and Bade. So, it is highly recommendable. ${ }^{\text {'33 }}$

${ }^{28}$ Ludwik Mierosławski, Jeu stratégique (Paris, 1850).

${ }^{29}$ On French military journalism, see Paddy Griffith, Military Thought in the French Army 1815-1851 (Manchester 1989), 62-67. 98.

30 "Jeu stratégique par le géneral Mierosławski," in Le spectateur militaire 49 (1850): 496-

31 Fournal de débats politiques et littéraires, unsigned review, March 21, 1850, 4.

32 Deutsches Wochenblatt fir constitutionelle Monarchie, "Allerlei," November 24, 1850, 376.

33 Deutsche Wehr-Zeitung, "Tages-Ereignisse, Herr Mierosławski [...]," November 7, $1850,1504-5$.

Board Game Studies Journal 14, pp. 17-42 DOI: $10.2478 /$ bgs-2020-0002 
Mierosławski envisioned a wide diffusion of his invention and therefore sought to formulate the game rules as simple as possible. This was indeed consistent with Mierosławski's image of himself as a public educationalist, which in mid-1850 was further nurtured by his employment as a teacher of History and Geography at the renowned boys' boarding school of JeanFrançois Barbet at Paris. ${ }^{34}$ In this institution students were prepared for the Grandes écoles and many became well-known characters: Louis Pasteur, Charles-Denis Bourbaki or François-Achille Bazaine all once attended Barbets institution. Because military science was an important element in the school's curriculum, Mierosławski was predestined to teach there. Especially his famous History lessons were enriched by many military references. One of his pupils later remembered: "So impressive and thrilling was his lecture that even the usually inattentive students listened devotedly. Above all Mierostawski's face was captivating. It resembled that of Christ, was framed by a red beard and showed considerable expression when he talked about past battles. [...] His look, generally relaxed and regular, then took on the wild expression of the war heroes one can find on paintings." 35 It seems highly probable that Mierosławski used his strategy game for illustrational purposes during his lessons. This explains why he finally came to the idea that the invention was particularly suited to make historical and geographical facts more accessible to students.

From this moment on Mierosławski showed an increasing conviction to introduce his game at the public schools in France. To this end, he worked on the fourth and final edition of the game rules, which were published in 1857. ${ }^{36}$ This time, people were invited to participate in demonstrations of the game at the Dumaine bookstore in order to create further attraction. Because Mierosławski now intended to commercialize his creation as a didactic aid, in an addition to the fourth edition he stated: "Invented mainly for students at specialized schools and above all for candidates at the military academies, this game method can contribute to the historical and geographical education at higher schools. ${ }^{\prime 37}$

Everything Mierosławski needed was the recommendation of his game by established experts. In November 1857 he contacted the Societé pour

\footnotetext{
${ }^{34}$ Victor Chauvin, Histoire des lycées et colléges de Paris (Paris, 1866), 200-1; "Les lycées et colléges de Paris," in Revue de l'instruction publique de la littérature et des sciences 25 (1866): 124.

${ }_{35}$ Adrien Marx, Silhouettes de mon temps (Paris, 1889), 74.

${ }^{36}$ Ludwik Mierosławski, Jeu stratégique et géographique (Paris, 1857).

37 ibid., Appendix, 9.
} 
l'instruction publique, a pedagogic society committed to the development of the French school system and quite influential in educational circles. Mierosławski sent all material concerning his game and requested a professional evaluation of the invention by the society members. The Societé, granting his request, appointed a commission consisting of the entomologist Charles Jean Amyot and the teachers Charles Sédail and Auguste Braud. ${ }^{38}$ An extensive report on the game was published by the commission in January 1858, which emphasized, that especially "cadets and officers on garrison duty could not use their spare time in a more useful way." 39 Yet, despite offering several didactic advantages, the commission remained skeptical regarding the introduction of Mierosławski's game at public schools. It was the supposed lack of discipline on the side of the students that concerned the commission most. The members realized that teachers in classroom had to act as umpires and were required to observe too many groups at the same time, thus being unable to guarantee a fair game flow - an evaluation that shattered Mierosławski's high hopes regarding the distribution of his invention at French public schools. He nevertheless thanked the Societé for an otherwise quite positive review and promised the publication of new game boards soon. ${ }^{40}$

In seeking more support and advertisement for his game, Mierosławski contacted several other experts with scientific background, mostly historians, mathematicians and military officers. Among the numerous renowned advocates of his game were the historian Jules Michelet and the geographer Edmé François Jomard. Supporters from military circles included the staff officer Camille Ferri-Pisani, aide-de-camp to Prince Napoleon, and Captain Jean-Jacques Colin, who was a teacher at the St. Cyr military academy.

Since the last months of 1857, Mierosławski was already working in close connection with Augustin Grosselin, a member of the Societé. The latter was a stenographer, educationalist and inventor of a sign language, but he was above all the owner of a company which sold a great variety of innovative educational materials. It was Grosselin who put the final touches to the

38 “Correspondance," in fournal d'éducation populaire 59 (1857): 437-38.

39 Auguste Braud, "Jeu géographique et stratégique, par le général L. Mierosławski," in Fournal d'éducation populaire 61 (1858): 25-28.

40 "Correspondance," Journal d'éducation populaire 63 (1858): 85-86. 
exterior of Mierosławski's game: The rule book was now accompanied by a small wooden box that contained the game pieces suitable for four players. The various game boards were lithographed by Adam Pilinski, a polish émigré and skilled artist, and glued to cardboard. ${ }^{41}$ They could be bought in the French paper sizes Jésus $(56 \times 72 \mathrm{~cm})$ and Double Carée $(56 \times 90 \mathrm{~cm})$. The catalogue of Grosselin contained at first only game boards of Hungary and France. But in 1858 other theaters of war such as Germany, the Balkans and the Po valley were added. The different editions of the game varied considerably in price. A complete game board with box and pieces for two players was sold for 8 Francs. The most luxurious version stood at 24 Francs and contained two game boards with pieces for four players. Some contemporary examples of lower wages may help to put the price of the game in perspective: Around 1850 the annual pay of a French SousLieutenant was 1.350 Francs. ${ }^{42}$ Depending on occupation a manual worker in Paris earned between two and four Francs a day and had to pay an annual rent of 120-160 Francs for accommodation. ${ }^{43}$ In view of these circumstances, the price of the game was fairly moderate; more so if considered that the new edition was aimed at officers, teachers and the educated bourgeoisie in general.

Since the sources do not contain any numbers on sold game sets or other indications in this regard, it is not possible to assess the actual success of the whole project. Several French newspapers advertised the game until 1859, but there are no more published reviews. In the same year, Grosselin decided to create a special catalogue that included Mierosławski's game and which was intended for private households with children. ${ }^{44}$

\section{Conclusion}

At this time, Mierosławski realized that the concept of his invention was exhausted and after more than ten years of development he put this project to a final rest. Shortly after the publication of the fourth edition of his game

${ }^{41}$ Adam Pilinski et ses travaux (Paris, 1890), 3-8.

${ }^{42}$ Antoine Rufin, Manuel d'administration et de comptabilité a l'usage des officers et sous-officiers des compagnies ou escadrons des corps d'infanterie et de cavalerie (Strasbourg, 1853), 60.

43 Alfred Legoyt, La France et l'Étranger. Études de statistique comparée (Paris 1870), 2:5556 ; Ann-Louise Shapiro, Housing the Poor of Paris 1850-1902 (Madison, 1985), 38.

44 "Méthodes d'enseignement," La science des mères, April/May 1859, 40.

Board Game Studies Journal 14, pp. 17-42 DOI: $10.2478 /$ bgs-2020-0002 
rules, Mierosławski was busy writing political papers and designing military operations. Between 1860 and 1862, he got completely absorbed in the movement for Italian independence and was recruiting Polish émigrés for service in Giuseppe Garibaldi's International Legion. The following year, he headed the Polish January Uprisings, but returned to Paris after the failure of the revolt. Mierosławski's inventive mind was not destined to rest yet and between 1863 and 1870, he worked on several new creations, among them an early tank vehicle (char hussite, camp roulant) and a bulletproof knapsack that could be used as a shield (sac-bouclier). ${ }^{45}$ Unlike his strategy game, these inventions rapidly proved themselves ineffective. In 1871, at the end of the Franco-Prussian War, the inventor himself offered the Commune of Lyon some drafts of his creations, but they turned out to be of little use and did not bear any effect on the outcome of the war.

Mierosławski was a keen and brilliant observer and was much impressed with the Prussian military victories during the German Wars of Unification. Not a few of his contemporaries derived these successes from the Kriegsspiel. The latter was a sophisticated type of map maneuver used throughout the Prussian Army to train front line officers in tactical decision making. ${ }^{46}$ Familiar with the Kriegsspiel rules of Reisswitz and Tschischwitz and their advantages, Mierosławski was one of the first advocates of this method, and recommended its introduction to the French Army. At the same time he remained a strong critic of the rigid Prussian rules which led him to state: "The German pedantry has not made the Kriegsspiel a method for practical instruction, but instead a game of incomprehensible logistics for arrogant general staff officers. ${ }^{47}$ As an alternative he proposed a revised version of his game rules, whose details were unfortunately not published and the French Army did not adopt them.

There was no tradition of Kriegsspiel or theoretical map maneuvers in the French Army at the time and the German manuals, translated between 1874 and 1900, were rarely used. In contrast to France, numerous other

${ }^{45}$ Ludwik Mierosławski, Theorie des manœuvres avec le sac-bouclier (Paris, 1871); Ludwik Mierosławski, Le camp roulant de Lyon devant le ministère de la guerre, la commission des marchés et l'Assemblée nationale (Paris, 1873); Tadeusz Grab, "Wojsko powstancze pomysłu Ludwika Mierosławskiego," Studia z Dziejow Wojskowosci 3 (2014): 131-65.

46 Konstantin von Altrock, Das Kriegsspiel. Eine Anleitung zu seiner Handhabung (Berlin, 1908), 1-8; Jorit Wintjes, "When a Spiel is not a Game: The Prussian Kriegsspiel from 1824 to 1871," Vulcan 5 (2017): 5-28.

47 "Chronique Mensuelle," in Le spectateur militaire 31/3 (1873): 137-38.

Board Game Studies Journal 14, pp. 17-42 DOI: $10.2478 /$ bgs-2020-0002 
armies worldwide took on the example of Kriegsspiel, which created much military prestige for the German army. Soon, France was looking for some models of her own and found Mierosławski's game. Since 1873 Mierosławski was regarded as the inventor of the Kriegsspiel in France. ${ }^{48}$ The journal Le Temps published a similar statement and wrote: "One forgets that this game [the Kriegsspiel] - like it is used today in the German and Austrian armies was made perfect by a courageous fighter of 1848 [Mierostawski] and offered to the French Army. "49 Five years later the journal Le Petit Parisien assured that "Mierostawski's inventions are in great esteem in Germany and Austria." "50

The truth was that already in the last years of the $19^{\text {th }}$ century, no more references to Mierosławski's game were made in newspapers or other publications. The limited number of copies might have led to only a moderate distribution, which explains why it remained forgotten to this day. Not even the relevant scientific biographies of Mierosławski mention its existence. ${ }^{51}$ Today, only four copies of the game rules can be found in public libraries worldwide and they seem to be all that remain of Mierosławski's extraordinary invention. ${ }^{52}$ The development of the game had an enormous importance for Mierosławski and over a period of eleven years he regularly tried to improve it - even when pursuing other parallel and often changing projects. Ludwig Mierosławski died in 1878 and was buried at the cemetery Montparnasse in Paris.

48 "Chronique Mensuelle," in Le spectateur militaire 30/3 (1873): 445-46.

${ }^{49}$ Le Temps, "La vie militaire," November 16, 1886, 2.

50 Le Petit Parisien, "Le Jeu de la Guerre," February 5, 1891, 1.

51 The most complete biographies by Chmiel and Zychowski (see reference no. 4) do not mention the game.

${ }^{52}$ The search was conducted with the Karlsruhe virtual catalogue (KVK). Two copies of the second edition (1849) are preserved at the Canton Library Aargau, Sign. AKB He4627 and at the National Library of Poland at Warsaw, Sign. 39.179. Two copies of the fourth edition (1857) are located at the Bibliothéque nationale de France at Paris, Inv. Nr. V-46807 and at the National Library of Poland at Warsaw, Sign. 99.978.

Board Game Studies Journal 14, pp. 17-42 DOI: $10.2478 /$ bgs-2020-0002 


\section{Synopsis of the game rules}

\section{Material}

The last edition of Mierosławski's game rules dating from 1857 has been digitized by the Bibliothèque Nationale Française and is available for download. ${ }^{53}$ The game board can be found in the middle of the booklet and has to be printed on a far larger scale. A reconstruction of the original conic and funnel-shaped game pieces is not advisable. Instead, cubes made of wood or brass that are painted red and blue to distinguish sides, proved to be much more practical. Of course, the size of these pieces should be kept in a reasonable proportion to the game board.

\section{Game piece characteristics}

Mierosławski's game requires only the following three types of pieces per player.

Great General Staff: 1 piece. This is the most important piece of the game. If it is lost, so is the game. It is the player's aim to move the Great General Staff from his own capital into the capital of the opponent without losing it on the way. The Great General Staff has no ability to attack or defend and is reliant on the protection of the Divisions.

Divisions: 20 pieces. The function of the Divisions is to occupy road intersections, cities and fortresses. In doing so, it is a primary mission of the Divisions to cover the movements of the vulnerable Great General Staff.

Little General Staff: 5 pieces. The only mission of these pieces is to occupy the opponent's province capitals. Does a Little General Staff achieve this goal, the opponent loses all his pieces during the game turn and within this province. Only units within a fortress are immune. This procedure is observed only once per province and per game. For beginners, it is advisable to play without the Little General Staff piece and concentrate on the core rules of the game instead.

${ }^{53}$ http://gallica.bnf.fr/ark:/12148/bpt6k1414127n 


\section{Initial position}

A die decides which player has the right to choose his territory/his side on the game board. Every player then gets the 26 pieces mentioned above. The first player places his pieces on the game board, the second player follows. Mierosławski mentions an alternative and more realistic method in which a cardboard screen is placed along the border of the two territories so that neither player is able to observe the initial position of the opponent's pieces. The pieces are placed on strategic points, i.e. on the corners of the triangles that represent the road net. Restrictions are: 1.) The initial position of the Great General Staff is one's own the capital. 2.) At the beginning the 20 Divisions must be divided in 5 groups (corps) à 4 Divisions. However, the player is free to place these groups as he wishes. 3.) The Little General Staff pieces may be placed at will, but only separate from each other and the other pieces. It is true for the whole game that Great General Staff, Little General Staff or Divisions are never placed together, i.e. intermingled on a strategic station.

\section{Course of the game}

Mierosławski's invention is a turn-based game and each player is free to move all his pieces during one turn. He may also move only some or none at all. The movements are made along the lines on the game board, i.e. the sides of the triangle lines that represent the lines of strategic operations. The distance of a movement is always from one strategic point to another, i.e. from one point to the next. To prevent confusion, it is recommended to move the pieces at the left side of the game board first and then continue to the right side. The triangle sides on the game board represent a road net with roads of different quality that restrict the movement of troops, i.e. the Divisions. They are of the following order: 1 line $=$ a maximum of 1 Division can pass; 2 lines $=$ a maximum of 4 Divisions can pass; black/white striped $=$ an unlimited number of Divisions can pass. The different General Staff pieces can pass everywhere. During the game, the players are allowed to unite or divide the Divisions - grouped in 5 corps à 4 Divisions only before the first move - as they see fit. After a player has finished his turn, it is the opponent's move. 


\section{Combat resolution}

Only the Divisions possess offensive/defensive power, therefore these are the only pieces that can engage in combat. Opposing Divisions are said to be in combat if they are adjacent to each other, i.e. the distance between them is one triangle side. Should a strong force oppose a weaker one, then the latter must retreat during the next turn. If retreat/evasion is impossible or the player fails to do so, the pieces are lost. If Divisions of equal power are facing each other then they are said to be in equilibrium - a situation that is preserved until one side achieves superiority. This concept is true for threats from more than one direction. Example: 4 red Divisions are in equilibrium with 4 blue Divisions on an east-west axis. In the next turn, 4 blue Divisions move into combat range from the north, thereby threatening Red from another direction. In this case no addition of the blue Divisions takes place (8 vs. 4 ) because the game rules regard the combat in this example as to be divided in two separate groups. The ratio is considered on each side separately so that the 4 red Divisions in the situation mentioned above are in equilibrium with each of the separate two blue groups ( 4 vs. 4 east-west; 4 vs. 4 north-south). A predominance of Blue can only be achieved by reinforcements of one of his groups. Fortresses influence the power of the defense and are attributed with certain values: $1^{\text {st }}$ order fortress $=4$ Divisions; $2^{\text {nd }}$ order fortress $=2$ Divisions; $3^{\text {rd }}$ order fortress $=1$ Division. Example: 2 red Divisions have occupied a $1^{\text {st }}$ order fortress $(+4)$ and therefore possess a defensive power of 6 . The attacker now needs a minimum of 7 Divisions to force the retreat of Red. Because of this rule set it is also possible for 1 Division to defend a mountain pass (1 line) indefinitely since the opponent is not permitted to move more than one Division along such a line.

The General Staff pieces possess no offensive/defensive powers but can block strategic points for opposing General Staff pieces. When confronted with Divisions, the General Staff pieces must retreat and there are no defensive advantages for the occupation of fortresses.

The winner is the first player who succeeds in moving his Great General Staff piece into the opponents' capital. 


\section{References}

[Altrock, 1908] Altrock, K. v. (1908) Das Kriegsspiel. Eine Anleitung zu seiner Handhabung. Berlin: Mittler.

[Anon., 1848] Anon. (1848) Protokolle der Deutschen Bundesversammlung vom Fahre 1848. Frankfurt: Krebs-Schmitt.

(1849) Bundesblatt der Schweizerischen Eidgenossenschaft, vol. 2. Bern: Stämpfli.

- (1850) 'Jeu stratégique par le géneral Mierosławski', Le spectateur militaire, 49, pp. 496-498.

(1857) 'Correspondance', Fournal d'éducation populaire, 59, pp. 437438.

— (1858) 'Correspondance', Fournal d'éducation populaire, 63, pp. 85-86.

- (1859) 'Méthodes d'enseignement', La science des mères, April/May 1859, p. 40 .

- (1866) 'Les lycées et colléges de Paris', Revue de l'instruction publique de la littérature et des sciences, 25, p. 124.

— (1890) Adam Pilinski et ses travaux. Paris: E. Paul Labitte.

[Braud, 1858] Braud, A. (1858) 'Jeu géographique et stratégique, par le général L. Mierosławski', Journal d'éducation populaire, 61, pp. 25-28.

[Chauvin, 1866] Chauvin, V. (1866) Histoire des lycées et colléges de Paris. Paris: Hachette.

[Chmiel, 1975] Chmiel, L. (1975) Generat Ludwig Mierostawski 1814-1878. Warsaw: s.n. 
[Engberg-Pedersen, 2015] Engberg-Pedersen, A. (2015) Empire of Chance. The Napoleonic Wars and the Disorder of Things. Cambridge: Harvard University Press.

[Fuchs, 2006] Fuchs, D. (2006) 'Der große Polenprozess in Berlin und Bettina von Arnims Engagement für den angeklagten Mierosławski' in Franke, J. (ed.) Ein europäischer Freiheitskämpfer. Ludwig Mierostawski 18141878. Berlin: Christian \& Cornelius Rüss, pp. 19-38.

[Gembarzewski, 1925] Gembarzewski, B. (1925) Rodowy putków polskich $i$ oddziatów równorzednych od r. 1717 do r. 1831. Warsaw: Towarzystwo Wiedzy Wojskowej.

[Gill, 1974] Gill, A. (1974) Die Polnische Revolution 1846. Zwischen nationalem Befreiungskampf des Landadels und antifeudaler Bauernerhebung. Munich: Oldenbourg.

[Grab, 2014] Grab, T. (2014) 'Wojsko powstancze pomysłu Ludwika Mierosławskiego', Studia z Dziejow Wojskowosci, 3, pp. 131-65.

[Griffith, 1989] Griffith, P. (1989) Military Thought in the French Army 18151851. Manchester: Manchester University Press.

[Hellwig, 1780] Hellwig, J. (1780) Versuch eines aufs Schach-Spiel gebauten taktischen Spiels. Leipzig: S. L. Crusius.

[Julius, 1848] Julius, G. (ed.) (1848) Der Polenprozeß. Proze $\beta$ von dem Staatsanwalte bei dem Königlichen Kammergerichte als Betheiligte bei dem Unternehmen zur Wiederherstellung eines polnischen Staates in den Grenzen vor 1772 wegen Hochverraths angeklagten 254 Polen. Berlin: A.W. Hayn.

[Keller, 1935] Keller, H. G. (1935) Die politischen Verlagsanstalten und Druckereien in der Schweiz 1840-1848. Ihre Bedeutung für die Vorgeschichte der Deutschen Revolution von 1848. Bern: Paul Haupt. 
[Kermann, 2002] Kermann, J. (2002) 'Die pfälzische Revolution und die Rolle der Polen', in Rehm, C. (eds.) Baden 1848/49. Bewältigung und Nachwirkung einer Revolution. Stuttgart: Thorbecke, pp. 95-132.

[Knapp, 1975] Knapp, B. (1975) Ludwik Mierosławski, ,Obergeneral' der Revolutionsarmee. Die Mitwirkung von Polen an der badischen Volkserhebung des Jahres 1849 im Lichte des gesamtpolitischen Freiheitskampfes. Zeitschrift fuir Geschichte des Oberrheins. 123, pp. 227-241.

[Legoyt, 1870] Legoyt, A. (1870) La France et l'Étranger. Études de statistique comparée (2 vols). Paris: Veuve Berger-Levrault.

[Lewin, 2012] Lewin, G. G. (2012) War Games and their History. Stroud: Fonthill.

[Marx, 1889] Marx, A. (1889) Silhouettes de mon temps. Paris: E. Dentu.

[Messmer, 1819] Messmer, J. A. (1819) Het strategisch spel, of Militaire uitspanning. The Hague: Weduwe J. Allart.

— (1820) Das Feldzugsspiel oder Militärische Erholungen zum Vergnügen und Unterricht. The Hague: s.n.

[Mierosławski, 1835] Mierosławski, L. (1835) Bitwa grochowska. Paris: Ksiegarni Polskiej.

— (1835) Szuja. Paris: Ksiegarni Polskiej.

— (1836) Histoire de la révolution de Pologne. Paris: A. Jelowicki.

(1836) Pugaczow. Paris: Ksiegarni Polskiej.

— (1836) Zelazna Maryna. Paris: Ksiegarni Polskiej.

- (1840) Kurs sztuki wojskowej. Paris: s.n.

— (1842) Histoire de la révolution de 1830 à 1831. Paris: A. Jelowicki. 
(1842) Rozibior krytyczny kampanii 1831 roku i wywnioskowane z niej prawidta di wojny narodowej (2 vols). Paris: Martinet.

— (1847) Échecs polonaise. Berlin: Wilhelm Bothe.

- (1847) Kritische Darstellung des Feldzugs vom Fahre 1831 und hieraus abgeleitete Regeln für Nationalkriege. Berlin: B. Behr.

— (1848) Objasnienie gry szachow. Berlin: Wilhelm Bothe.

— (1848) Szachy polskie. Berlin: Wilhelm Bothe.

(1849) Berichte des Generals Mieroslawski über den Feldzug in Baden. Bern: Jenni.

- (1849) Jeu stratégique. Bern: Jenni.

Jenni.

(1849) Rapports du général Mierostawski sur la campagne de Bade. Bern:

— (1850) Jeu stratégique. Paris: Martinet/Dumaine.

— (1857) Jeu stratégique et géographique. Paris: Bureau Central.

— (1871) Theorie des mancuvres avec le sac-bouclier. Paris: Dumaine.

- (1873) Le camp roulant de Lyon devant le ministère de la guerre, la commission des marchés et l'Assemblée nationale. Paris: Dumaine.

[Müller, 2001] Müller, T. C. (2001) Der Schmuggel politischer Schriften. Bedingung exilliterarischer Öffentlichkeit in der Schweiz und im Deutschen Bund (1830-1848). Tübingen: Max Niemeyer.

[Pabst, 1850] Pabst, C. W. (1850) Der Feldzug gegen die badisch-pfälzische Insurrection im Fahre 1849. Darmstadt: Ludwig Pabst.

[Reisswitz, 1824] Reisswitz, J. G. (1824) Anleitung zur Darstellung militärischer Manöver mit dem Apparat des Kriegs-Spieles. Berlin: Mittler. 
[Rufin, 1853] Rufin, A. (1853) Manuel d'administration et de comptabilité a l'usage des officers et sous-officiers des compagnies ou escadrons des corps d'infanterie et de cavalerie. Strasbourg: Berger-Levrault.

[Rüstow, 1879] Rüstow, W. (1879) Die Feldherrnkunst des neunzehnten Jahrhunderts (2 vols). Zurich: Friedrich Schulthess.

[Schädler, 2016] Schädler, U. (2016) 'Prekäre Ordnung. ,Kriegsspiele' Panoramablick auf ein schwieriges Kompositum', in Strouhal, E. (ed.) Agon und Ares. Der Krieg und die Spiele. Frankfurt/New York: Campus, pp. 23-44.

[Shapiro, 1985] Shapiro, A.-L. (1985) Housing the Poor of Paris 1850-1902. Madison: University of Wisconsin Press.

[Sokolnicki, 1910] Sokolnicki, M. (1910) Les origines de l'emigration polonaise en France (1831-1832). Paris: F. Alcan.

[Venturini, 1797] Venturini, G. (1797) Beschreibung und Regeln eines neuen Krieges-Spiels. Schleswig: J. G. Rhöss.

[Winckler, 1846] Winckler, — (1846) Allgemeiner Wohnungsanzeiger für Berlin, Charlottenburg und Umgebung auf das Jahr 1846. Berlin: Veit.

[Wintjes, 2017] Wintjes, J. (2017) 'When a Spiel is not a Game: The Prussian Kriegsspiel from 1824 to 1871’, Vulcan, 5, pp. 5-28.

Zychowski, M. (1963) Ludwig Mieroslawski 1814-1878. Warsaw: Iskry. 


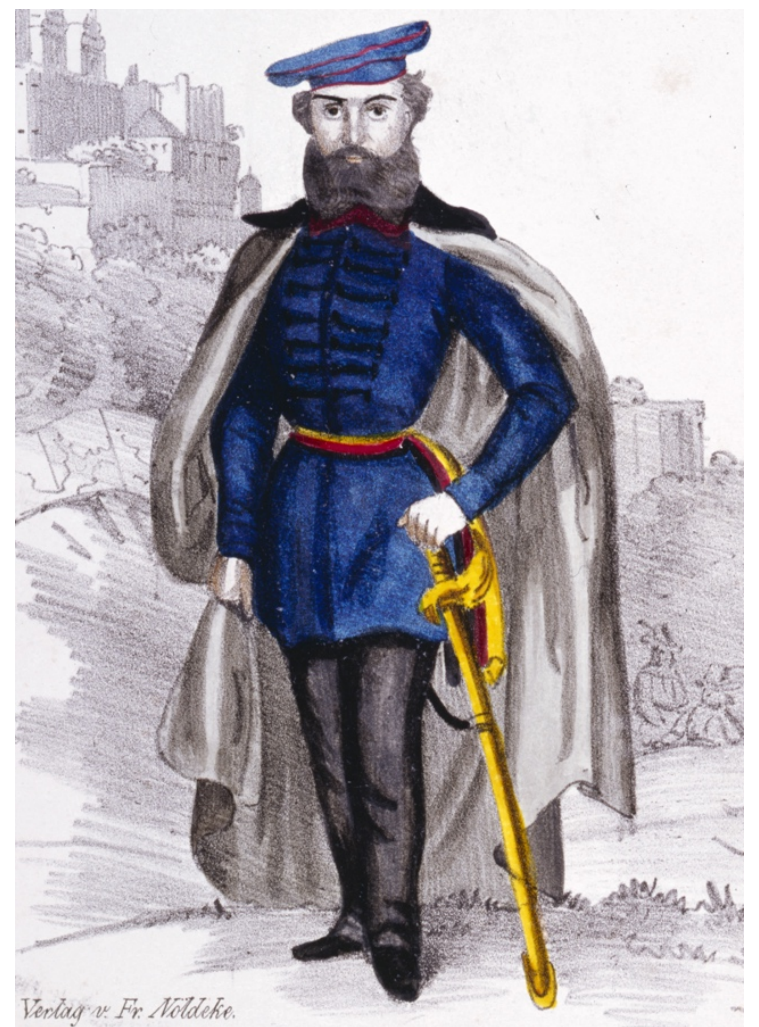

Figure 1: Ludwik Mierosławski as Commander-in-Chief of the Revolutionary Army of Baden and the Palatinate (Deutsches Historisches Museum Berlin, Inv. GR103134). 


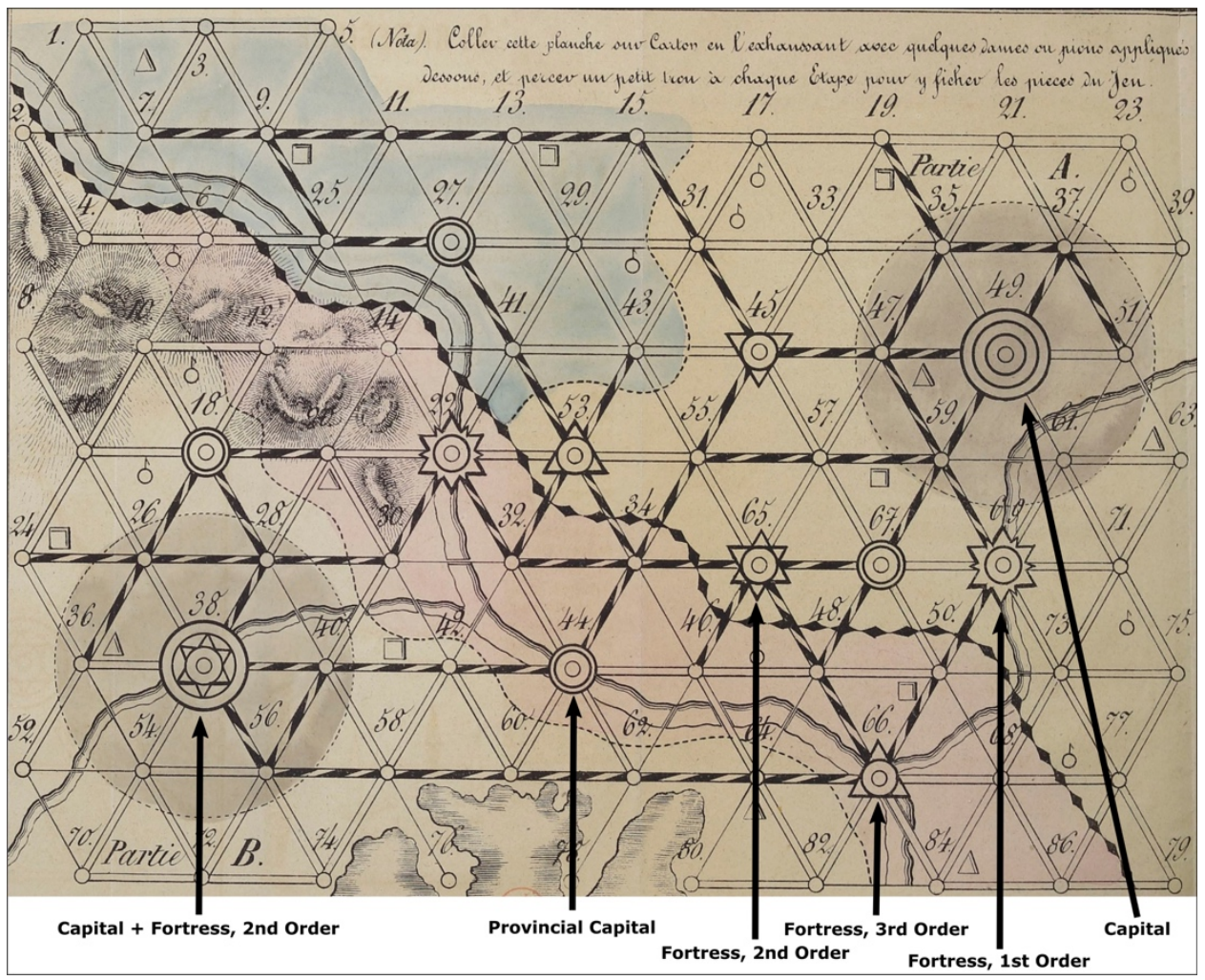

Figure 2: Game board, showing the Danube Region (Bibliothèque nationale de France Paris, Inv. V-46807. Explanatory notes are from the author).

\section{PIECES DU JEU.}

De chaque coté 20 Divisiono maruchant vémico on séporicéen, 1 Grano Elat- Mlajor et 5 Petito Etats- Mlajois marchant tonjows sógravés.

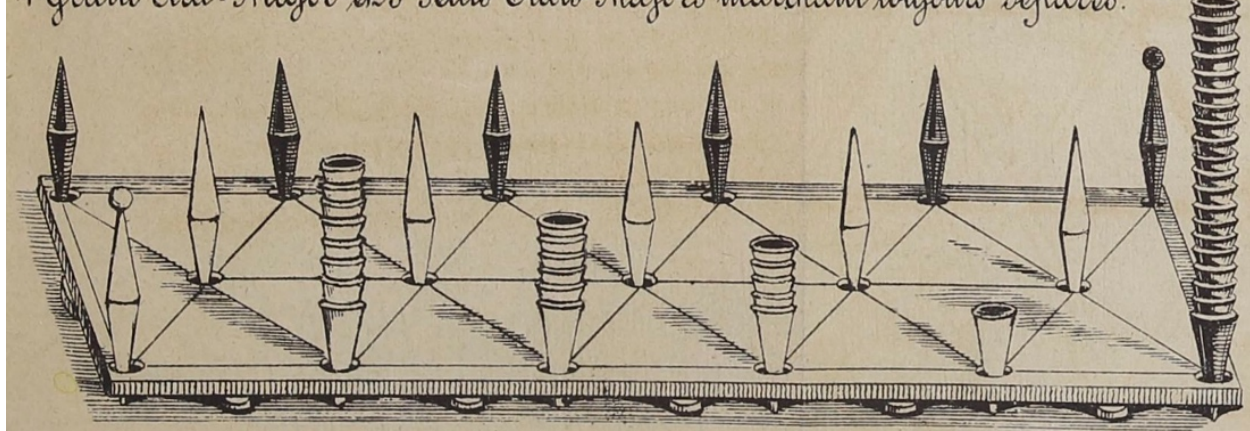

Figure 3: View of the original game pieces (Bibliothèque nationale de France Paris, Inv. V46807). 


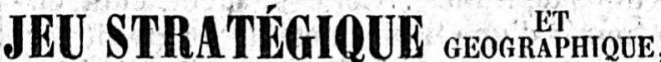 par le genéral Louis Mieroslawski. - Chez M. Gros: selin, éditeur de splères el Cartes géographiques,} ruc Serpente, 25.

Figure 4: Advertisement (Journal des débats politiques et littéraires, December 30, 1857, p. 4).

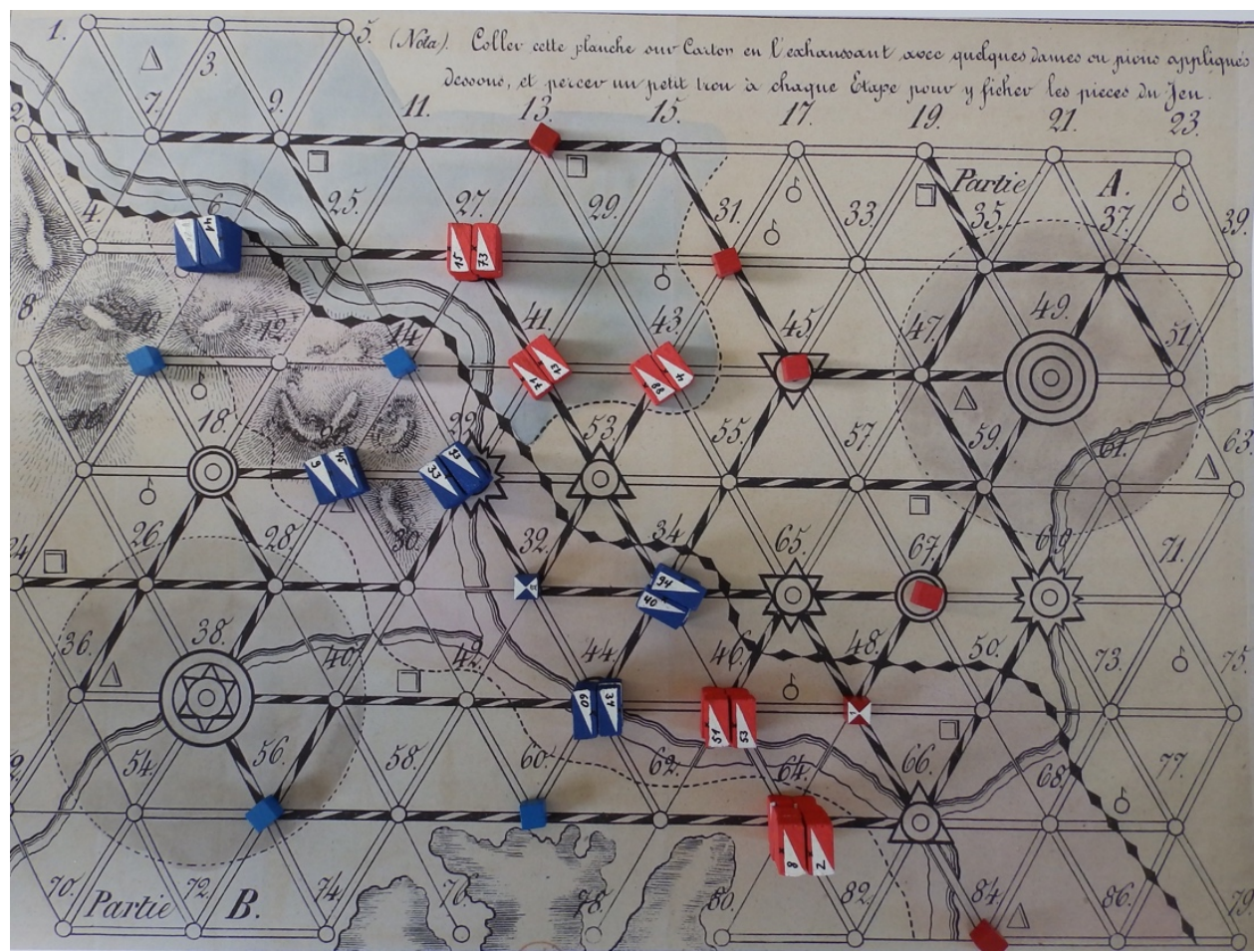

Figure 5: View of the game board with altered game pieces to facilitate handling (author's photo). 